\title{
KESESUAIAN STANDAR SARANA PRASARANA SMK KOMPETENSI KEAHLIAN DESAIN PEMODELAN DAN INFORMASI BANGUNAN (Studi pada SMKN 56 Jakarta dan SMKN 35 Jakarta)
}

\author{
R. Eka Murtinugraha ${ }^{1}$, M. Agphin Ramadhan², Pelagia Lia Andarista ${ }^{3}$ \\ ${ }_{1,2,3}$ Pendidikan Teknik Bangunan, FT, UNJ \\ Email: agphin@unj.ac.id
}

\begin{abstract}
ABSTRAK
Penelitian ini bertujuan untuk mengetahui kesesuaian standar sarana dan prasarana kompetensi keahlian DPIB terhadap Permendikbud Nomor 34 Tahun 2018 tentang Standar Nasional SMK/MAK dan terhadap BSNP mengenai instrumen verifikasi untuk penyelenggaraan ujian praktik kejuruan di SMKN 56 Jakarta dan SMKN 35 Jakarta. Penelitian ini merupakan penelitian deskriptif kuantitatif. Teknik pengumpulan data menggunakan observasi, dan dokumentasi. Tingkat kesesuaian SMKN 56 Jakarta pada sarana ruang kelas sebesar 75\% (sesuai), dan prasarananya 50\% (kurang sesuai), sarana ruang praktik komputer 45,83\% (kurang sesuai), ruang praktik desain masinal 54,55\% (sesuai) dan prasarananya 32,14\% (kurang sesuai). Tingkat kesesuaian SMKN 35 Jakarta pada sarana ruang kelas sebesar $75 \%$ (sesuai) dan prasarananya 50\% (kurang sesuai), sarana ruang praktik komputer 58,3\% (sesuai) dan prasarananya 25\% (sangat kurang sesuai). Tingkat kesesuaian kondisi fisik SMKN 56 Jakarta pada sarana ruang kelas sebesar 75\% (sesuai), ruang praktik komputer 45,83\% (kurang sesuai), ruang praktik desain masinal 44,3\% (kurang sesuai). Tingkat kesesuaian kondisi fisik SMKN 35 Jakarta pada sarana ruang kelas sebesar 75\% (sesuai), dan sarana ruang praktik komputer 57,1 (sesuai).
\end{abstract}

Kata kunci: Kesesuaian, Sarana, Prasarana

ABSTRACT

The purpose of this research is to know the suitability of facilities and infrastucture on competency Modeling Design and Building Information (DPIB) adjust to Permendikbud Section 34 of 2018 about National Standard SMK/MAK and to BSNP regarding leveraging instruments for the vocational practice exams. This research method is utilizing descriptive quantitative. Information assortment procedures of this examination are by doing observation and documentation. The suitability level of class room facilities on SMKN 56 Jakarta is $75 \%$ (suitable), and infrastructure is 50\% (less suitable), computer practice room facilities is 45,83\% (less suitable), masinal design room is 54,55\% (suitable), and infrastructure is 32,14\% (less suitable). The suitability level of class room facilities on SMKN 35 Jakarta is $75 \%$ (suitable), and infrastructure is $50 \%$ (less suitable), practice room facilities is $58,3 \%$ (suitable), and infrastructure is $25 \%$ (very less suitable). The suitability level of the physical condition of class room facilities on SMKN 56 Jakarta is 75\% (suitable), computer practice room facilities is 45,83\% (less suitable), and masinal design room is 44,3\% (less suitable). The suitability level of the physical condition of class room facilities on SMKN 35 Jakarta is 75\% (suitable), practice room facilities is $57,1 \%$ (suitable).

Keywords: Suitability, facilities and infrastructure

\section{PENDAHULUAN}

Pendidikan merupakan salah satu hal yang berperan dalam menciptakan generasi bangsa yang kompeten. Seiring dengan berkembangnya zaman dan teknologi membuat pemerintah mengeluarkan aturanaturan maupun program-program baru agar pendidikan di Indonesia menjadi lebih baik.
Direktorat Jenderal Pendidikan Vokasi Kemdikbud telah mengeluarkan program baru yang dirilis pada tanggal 30 Juni 2020. Program tersebut yaitu Program Link \& Match (Pernikahan Massal) Program Soft Skill SMK Industri dan Dunia Kerja. Program ini memiliki tujuan supaya SMK mampu menghasilkan lulusan yang kompeten dalam bidangnya dan siap 
memasuki dunia kerja. Program tersebut dapat diwujudkan dengan mempersiapkan dan mencukupi kebutuhan-kebutuhan penting yang diperlukan, salah satunya yaitu sarana dan prasarana pendidikan. Kurang cukupnya sarana dan prasarana dapat menjadi suatu masalah yang berpengaruh pada keefektifan kegiatan pembelajaran dalam menghasilkan lulusan yang kompeten (Elviana, 2015, pp. 1-2). Apabila hal ini terjadi dapat mempengaruhi kelancaran program pada pembelajaran.

Berdasarkan Data Pokok SMK Kemdikbud tahun 2018, terdapat SMK di DKI Jakarta sebanyak 73 SMK Negeri, dan 510 SMK Swasta. Walaupun demikian, hanya terdapat enam SMK Negeri yang memiliki kompetensi keahlian Desain Pemodelan dan Informasi Bangunan (DPIB). Sedikitnya SMK dengan kompetensi keahlian DPIB dapat berpengaruh pada proses menghasilkan tenaga kerja yang kompeten. Syafiq (2018, p. 1) menyatakan bahwa seharusnya SMK mampu menyiapkan setiap siswanya supaya menjadi pribadi yang kompeten dan mampu untuk bersaing. Oleh karena itu sekolah perlu mempersiapkan secara optimal terkait hal-hal yang dapat mempengaruhi kelancaran proses pembelajaran dan perolehan nilai siswa salah satunya yaitu sarana prasarana.

Kompetensi keahlian DPIB di SMKN 56 Jakarta dan SMKN 35 Jakarta memiliki kapasitas maksimal 36 siswa untuk setiap ruang kelas maupun ruang praktik. Meskipun demikian, sarana yang disediakan oleh sekolah rata-rata tidak mencukupi kebutuhan setiap siswa. Oleh karena itu dapat dikatakan bahwa sarana dan prasarana yang tersedia tidak sebanding dengan jumlah siswa yang tersedia. Berdasarkan pengalaman Praktik Kerja Mengajar (PKM) dan observasi yang dilakukan ditemukan kendala terkait sarana prasarana pada kompetensi keahlian DPIB di SMKN 56 Jakarta dan SMKN 35 Jakarta. Kendalakendala tersebut yaitu terdapat beberapa komputer yang rusak serta tidak memiliki aplikasi autocad. Hal ini didukung dengan hasil wawancara yang telah dilakukan kepada Kepala Kompetensi Keahlian DPIB dan juru bengkel di SMKN 56 Jakarta dan SMKN 35 Jakarta. Mereka menyatakan hal yang sama bahwa beberapa komputer memang tidak terinstal aplikasi autocad dan hal tersebut membuat beberapa siswa tidak dapat menggunakan fasilitas sekolah. Hal ini membuat siswa menggunakan laptop pribadi yang dibawa ke sekolah. Kepala Kompetensi Keahlian DPIB SMKN 56 Jakarta juga menyatakan bahwa kendala ini tentu mempengaruhi kinerja siswa, dikarenakan tidak semua laptop yang dimiliki siswa bahkan komputer yang disediakan mumpuni untuk mengoperasikan aplikasi autocad. Menurut Oktariansyah dkk (2019, p. 73) kemampuan siswa dalam merancang dan menggambar sebuah bangunan merupakan modal utama yang harus dimiliki oleh tenaga lulusan kompetensi keahlian DPIB. Oleh karena itu, diperlukan penunjang sarana yang baik dan mencukupi kebutuhan setiap siswa.

Kelancaran kegiatan pembelajaran selain didukung oleh sarana yang mumpuni tentu saja didukung pula dari kecukupan luas ruang untuk menampung setiap rombongan belajar. Sarifah (2017, pp. 1-2) menyatakan bahwa kegiatan pembelajaran praktik membutuhkan keleluasaan bergerak dalam ruangan supaya proses pembelajaran berjalan dengan lancar. Elviana (2015, pp. 1-2) juga menyatakan bahwa dengan cukupnya luas ruang, tenaga pengajar, dan prasarana penunjang sangat menentukan 
kenyamanan interaksi belajar siswa. Kondisi kelas yang nyaman sangat penting bagi kemampuan siswa dalam kegiatan pembelajaran sehingga yang pada akhirnya kegiatan pembelajaran dapat berjalan sesuai dengan harapan. Kegiatan pembelajaran dalam pendidikan nasional dapat terwujud apabila didukung dengan sarana dan prasarana yang memadai sesuai dengan ketentuan yang telah diatur (Havidotinnisa, 2016, p. 12). Pemerintah telah menyediakan peraturan yang dapat membuat sarana dan prasarana seluruh SMK yang ada setara dan sesuai dengan ketentuan yang telah ditetapkan. Penelitian ini menggunakan peraturan yang terbaru dan belum banyak digunakan pada penelitian di sekolahsekolah, termasuk pada kompetensi keahlian DPIB di SMKN 56 Jakarta dan SMKN 35 Jakarta. Peraturan tersebut diatur dalam Peraturan Menteri Pendidikan dan Kebudayaan Republik Indonesia Nomor 34 Tahun 2018. Peraturan tersebut mengatur tentang Standar Nasional Pendidikan untuk seluruh SMK/MAK di Indonesia. Selain itu, terkait spesifikasi sarana ruang praktik menggunakan instrumen verifikasi untuk kegiatan penyelenggaraan ujian praktik kejuruan di SMK/MAK Tahun Ajaran 2019/2020 dari Badan Standar Nasional Pendidikan (BSNP). Penelitian ini akan menghasilkan sebuah persentase kesesuaian sarana prasarana dengan kategori kesesuaian yang telah ditetapkan dan selanjutnya menjadi masukan bagi sekolah pada proses pengadaan sarana dan prasarana. Latar belakang penulis melakukan penelitian yaitu belum diketahuinya kesesuaian standar sarana dan prasarana pada kompetensi keahlian DPIB di SMKN 56 Jakarta dan SMKN 35 Jakarta terhadap peraturan minimum.

\section{METODE}

Pada penelitian ini penulis menggunakan metode penelitian deskriptif dengan pendekatan kuantitatif yang dilakukan pada bulan April 2020 sampai dengan bulan Januari 2021 di kompetensi keahlian DPIB SMKN 56 Jakarta dan SMKN 35 Jakarta. Teknik pengambilan sampel pada penelitian ini yaitu NonProbability Sampling dengan teknik Sampling Purposive. Pengumpulan data dilakukan dengan kegiatan observasi dan dokumentasi. Teknik analisis data pada penelitian ini dengan teknik statistik deskriptif dengan skala pengukuran yang dilakukan menggunakan rating scale.

\section{HASIL DAN PEMBAHASAN}

Berdasarkan hasil penelitian pada ruang kelas kompetensi keahlian DPIB di SMKN 56 Jakarta menunjukkan bahwa persentase kesesuaian sarana termasuk ke dalam kategori sesuai, dengan persentase kesesuaian sebesar $75 \%$. Kegiatan pembelajaran pada Ruang Kelas A yang merupakan Ruang Cendrawasih dapat dilakukan dengan baik karena sarana yang tersedia termasuk ke dalam kategori sesuai. Meskipun demikian, masih terdapat kekurangan pada sarana ruang kelas yang belum sesuai dengan standar minimum. Sarana yang kurang terpenuhi ketersediaannya dapat menimbulkan rasa ketidakpuasan siswa pada kegiatan pembelajaran, hal ini sependapat dengan Hidayatuloh (2019, p. 2) bahwa kurangnya ketersediaan sarana dapat mengurangi minat belajar siswa yang pada akhirnya dapat berdampak pada prestasi belajar siswa. 


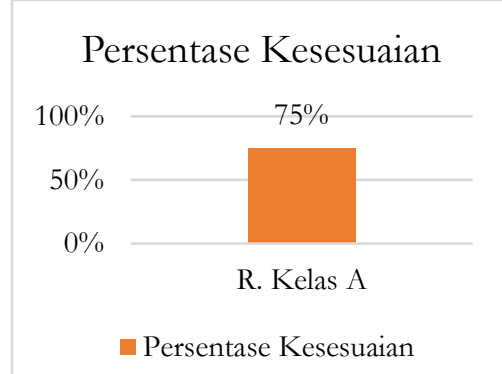

Gambar 1. Diagram Persentase Kesesuaian Sarana Ruang Kelas Kompetensi Keahlian DPIB SMKN 56 Jakarta

Hasil persentase kesesuaian pada prasarana ruang kelas kompetensi keahlian SMKN 56 Jakarta sebesar 50\% termasuk ke dalam kategori kurang sesuai. Pada kekurangan luas prasarana yang ada, sekolah dapat melakukan kegiatan prosedur pengadaan prasarana dengan melakukan pembelian, maupun menerima bantuan/hibah. Luas ruang kelas ini perlu menjadi perhatian bagi sekolah karena keleluasaan gerak dapat mempengaruhi kelancaran kegiatan pembelajaran. Hal ini sependapat dengan Elviana (2015, pp. 1-2) yang berpendapat bahwa cukupnya luas ruang, tenaga pengajar, dan prasarana penunjang sangat menentukan kenyamanan interaksi belajar siswa. Putri dkk (2016, p. 4) juga berpendapat bahwa ruang kelas yang penuh sesak dapat berpengaruh tidak baik terhadap pencapaian prestasi akademik.

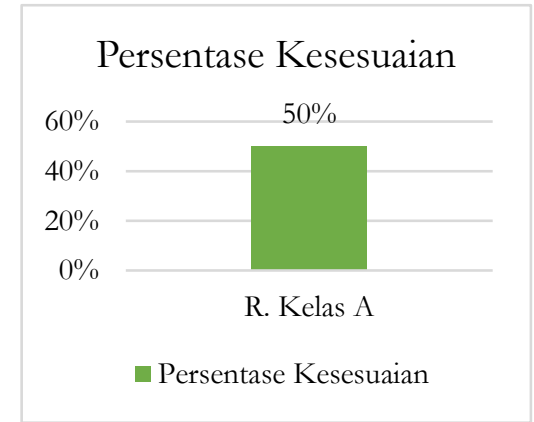

Gambar 2. Diagram Persentase Kesesuaian Prasarana Ruang Kelas Kompetensi Keahlian DPIB SMKN 56 Jakarta

Berdasarkan kegiatan observasi yang dilakukan pada kompetensi keahlian DPIB di SMKN 35 Jakarta didapati hasil dari penelitian pada ruang kelas menunjukkan bahwa rata-rata persentase kesesuaian sarana sebesar $75 \%$ termasuk ke dalam kategori sesuai. Kegiatan pembelajaran pada setiap ruang kelas dapat dilakukan dengan baik karena sarana yang ada termasuk ke dalam kategori sesuai. Legiwati (2016, p. 296) menyatakan bahwa sarana yang memadai dan sesuai dengan standar memungkinkan siswa untuk dapat termotivasi dalam mengikuti kegiatan pembelajaran yang pada akhirnya dapat meningkatkan hasil belajar siswa. Meskipun demikian, terdapat beberapa sarana ruang kelas yang belum mencukupi standar minimum yang ditetapkan berupa kursi dan meja siswa dan perlu menjadi perhatian.

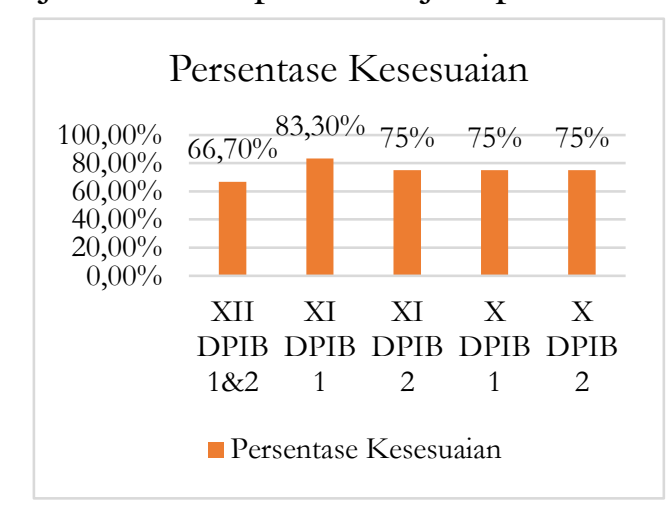

Gambar 3. Diagram Persentase Kesesuaian Sarana Ruang Kelas Kompetensi Keahlian DPIB SMKN 35 Jakarta

Hasil persentase kesesuaian pada prasarana ruang kelas kompetensi keahlian DPIB di SMKN 35 Jakarta rata-rata sebesar $50 \%$ termasuk ke dalam kategori kurang sesuai. Pada kekurangan prasarana yang ada, sekolah dapat melakukan kegiatan prosedur pengadaan prasarana dengan melakukan pembelian, maupun menerima bantuan/hibah. Keluasan ruang kelas yang belum memenuhi ketentuan minimum dapat berpengaruh pada lancarnya proses pembelajaran. Sudiyono dan Alip (2016, p. 
81) mengemukakan bahwa dengan tercapainya kebutuhan sarana prasarana dapat menghasilkan dampak positif bagi keberhasilan siswa dalam meraih pengetahuan, dan keterampilan sebagai bekal yang akan berguna pada saat memasuki dunia kerja.

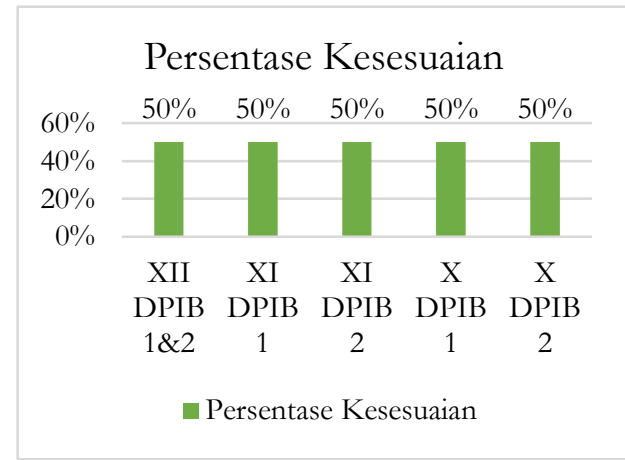

Gambar 4. Diagram Persentase Kesesuaian Prasarana Ruang Kelas Kompetensi Keahlian DPIB SMKN 35 Jakarta

Kompetensi keahlian DPIB di SMKN 56 Jakarta memiliki dua ruang praktik desain masinal, dan tiga ruang praktik komputer. Nama ruang tersebut yaitu Ruang Komputer A yang merupakan Ruang Wallet, Ruang Komputer B sebagai Ruang Nuri, Ruang Komputer C sebagai Ruang Murai, Ruang Desain Masinal A sebagai Ruang Merak, dan Ruang Desain Masinal B sebagai Ruang Bangau. Hasil penelitian pada ruang praktik komputer kompetensi keahlian DPIB di SMKN 56 Jakarta menunjukkan bahwa persentase kesesuaian sarana rata-rata sebesar $45,83 \%$ termasuk ke dalam kategori kurang sesuai. Selain itu, pada ruang praktik desain masinal kompetensi keahlian DPIB SMKN 56 Jakarta menunjukkan bahwa rata-rata persentase kesesuaian termasuk ke dalam kategori sesuai sebesar 54,55\%. Meskipun demikian, terdapat kebutuhan sarana berupa seperangkat peralatan praktik seperti komputer dan meja gambar, serta sarana lainnya pada beberapa ruang praktik belum mencukupi kebutuhan standar minimal yang dibutuhkan. Sarana yang memadai sangat diperlukan bagi setiap siswa mengingat bahwa kegiatan pembelajaran praktik di SMK berperan penting dalam menghasilkan lulusan yang kompeten. Hal ini sependapat dengan yang dikemukakan oleh Triono (2013, p. 6) bahwa apabila sarana prasarana pada SMK tidak memadai, maka hal ini akan mempengaruhi hasil lulusan SMK tersebut.

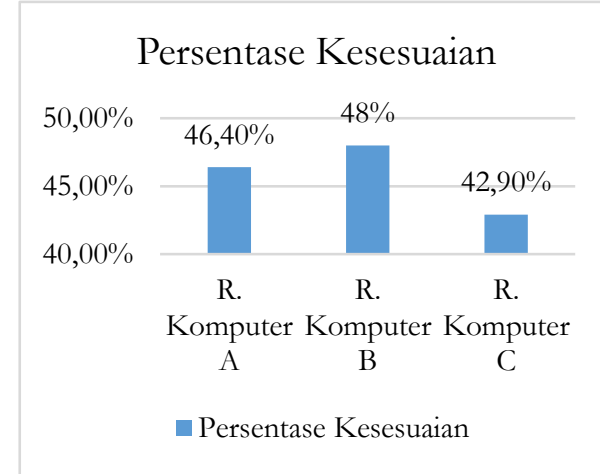

Gambar 5. Diagram Persentase Kesesuaian Sarana Ruang Praktik Komputer Kompetensi Keahlian DPIB SMKN 56 Jakarta

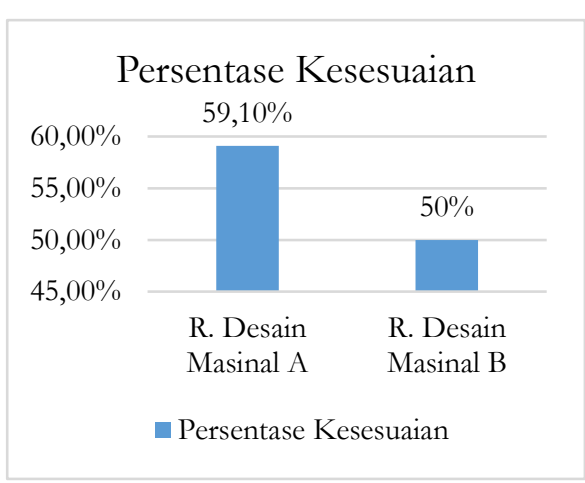

Gambar 6. Diagram Persentase Kesesuaian Sarana Ruang Praktik Desain Masinal Kompetensi Keahlian DPIB SMKN 56 Jakarta

Hasil persentase kesesuaian prasarana ruang praktik kompetensi keahlian DPIB di SMKN 56 Jakarta rata-rata sebesar $32,14 \%$ termasuk ke dalam kategori kurang sesuai. Ruang praktik dinyatakan kurang sesuai disebabkan oleh kurang luasnya beberapa ruang praktik, dan tidak adanya ruang praktik perencanaan dan pembuatan model/maket bangunan, serta ruang penyimpanan dan instruktur. Luas prasarana 
ruang yang memenuhi standar berpengaruh terhadap kegiatan pembelajaran. Sependapat dengan hal tersebut, Haryanto (2016, p. 5) mengemukakan bahwa sebagai penunjang kegiatan pembelajaran yang efektif, serta tercapainya tujuan pendidikan sesuai dengan yang diharapkan, maka dibutuhkan sarana dan prasarana yang memadai. Pada kekurangan prasarana yang ada, sekolah dapat melakukan kegiatan prosedur pengadaan prasarana dengan melakukan pembelian, maupun menerima bantuan/hibah.

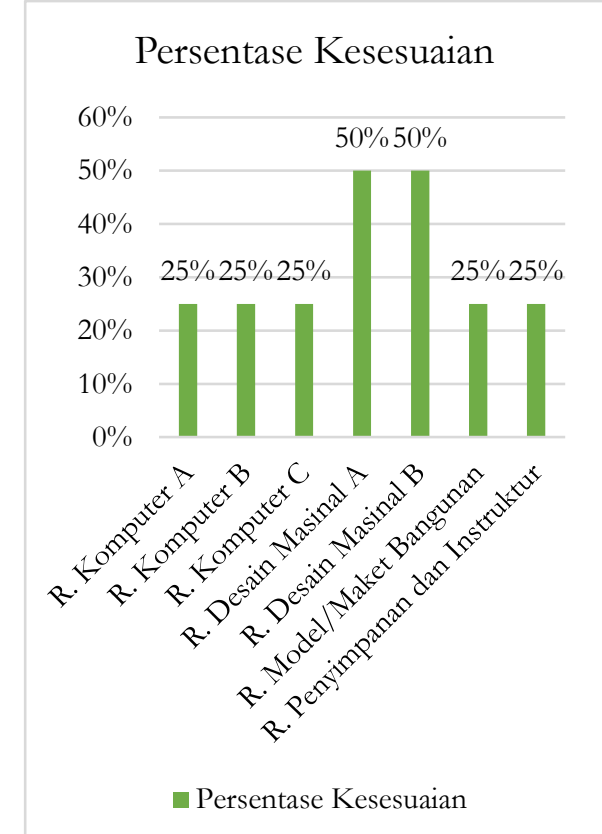

Gambar 7. Diagram Persentase Kesesuaian Prasarana Ruang Praktik Kompetensi Keahlian DPIB SMKN 56 Jakarta

Kompetensi keahlian DPIB di SMKN 35 Jakarta memiliki tiga ruang praktik komputer. Hasil penelitian pada ruang praktik komputer menunjukkan bahwa persentase kesesuaian sarana termasuk ke dalam kategori sesuai, dengan rata-rata sebesar 58,3\%. Kegiatan pembelajaran dapat dilakukan dengan baik pada ruang praktik ini karena sarana ruang praktik termasuk ke dalam kategori sesuai. Meskipun demikian, terdapat kebutuhan sarana berupa seperangkat peralatan praktik yaitu komputer serta sarana lainnya pada beberapa ruang praktik belum mencukupi kebutuhan standar minimal yang dibutuhkan. Sehubungan dengan hal itu, Syafiq (2018, p. 3) menyatakan bahwa kurangnya ketersediaan alat pembelajaran atau sarana serta prasarana pembelajaran khususnya untuk kegiatan praktikum di SMK dapat membuat kegiatan pembelajaran menjadi terhambat dan kurang maksimal.

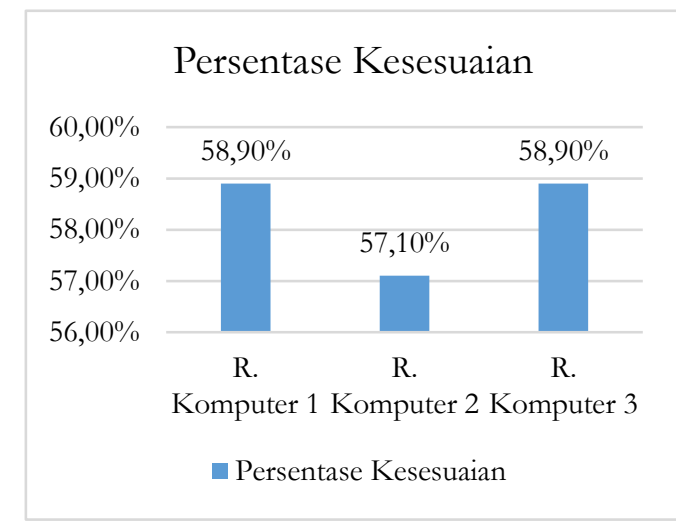

Gambar 8. Diagram Persentase Kesesuaian Sarana Ruang Praktik Komputer Kompetensi Keahlian DPIB SMKN 35 Jakarta

Hasil persentase kesesuaian prasarana ruang praktik kompetensi keahlian DPIB di SMKN 35 Jakarta termasuk ke dalam kategori sangat kurang sesuai, dengan rata-rata persentase kesesuaian sebesar $25 \%$. Kurang sesuai ruang praktik disebabkan oleh kurang luasnya beberapa ruang praktik, dan tidak adanya ruang praktik desain masinal, ruang praktik perencanaan dan pembuatan model/maket bangunan, serta ruang penyimpanan dan instruktur. Menurut Liliani dkk (2019, p. 2) dengan adanya sarana dan prasarana yang baik dapat menunjang proses pembelajaran baik secara langsung maupun tidak langsung guna mencapai tujuan yang diharapkan. Pada kekurangan prasarana yang ada, sekolah dapat melakukan kegiatan prosedur pengadaan prasarana dengan melakukan 
pembelian, maupun menerima bantuan/hibah.

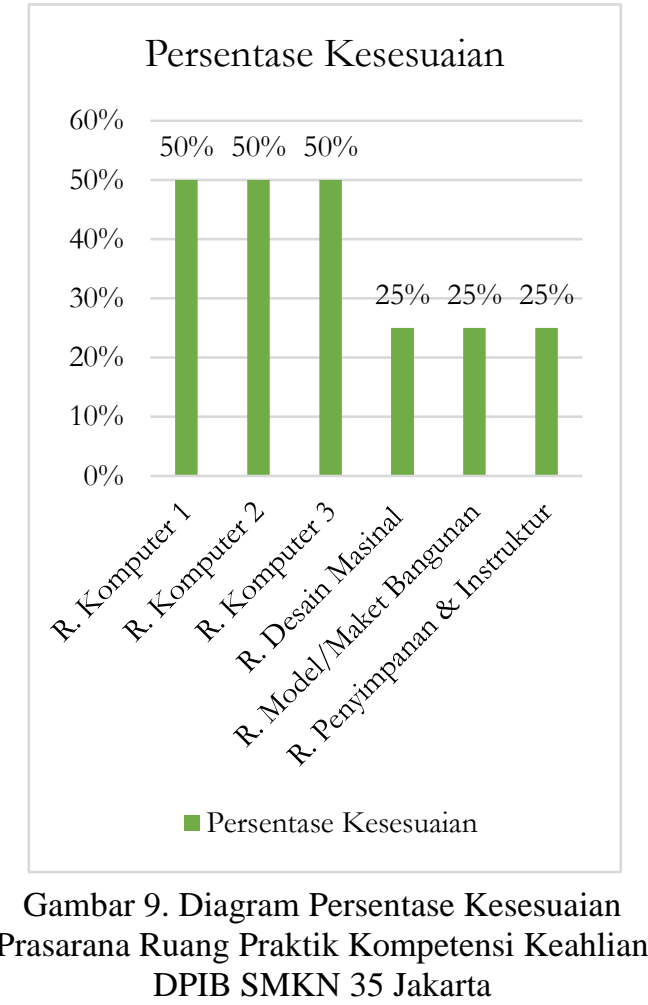

Berdasarkan dari kegiatan observasi didapatkan sebuah persentase kesesuaian terhadap kondisi fisik sarana yang diperoleh dari kondisi sarana ruang praktik yang dapat digunakan oleh siswa dengan baik. Hasil persentase kesesuaian terhadap kondisi fisik sarana pada ruang kelas kompetensi keahlian DPIB di SMKN 56 Jakarta sebesar 75\%. Hal ini berarti sarana yang ada pada ruang kelas layak untuk menunjang kegiatan pembelajaran. Sedangkan pada kondisi fisik sarana ruang praktik didapatkan persentase kesesuaian terhadap kondisi fisik sarana rata-rata ruang praktik komputer sebesar $45,83 \%$ termasuk kategori kurang sesuai. Selain itu, pada sarana ruang praktik desain masinal didapatkan persentase kesesuaian terhadap kondisi fisik sarana rata-rata sebesar 44,3\% termasuk kategori kurang sesuai. Hal ini menandakan bahwa sarana yang ada pada ruang praktik kurang layak untuk menunjang kegiatan pembelajaran.
Rahardiani dkk (2017, p. 3) menyatakan bahwa sarana yang baik dan sesuai dengan ketentuan minimum menjadi salah satu elemen yang penting dalam meningkatkan kompetensi siswa pada kegiatan pembelajaran. Sarifah (2017, p. 1) juga menyatakan bahwa sarana yang ergonomis sesuai dengan kebutuhan setiap siswa dapat menciptakan kenyamanan di tempat praktik. Pada kekurangan sarana yang ada, sekolah dapat melakukan kegiatan prosedur pengadaan sarana dengan melakukan pembelian, perbaikan, pembuatan sendiri, maupun menerima bantuan/hibah. Terkait sarana yang sudah sesuai diperlukan proses pemeliharaan dan perawatan sarana.

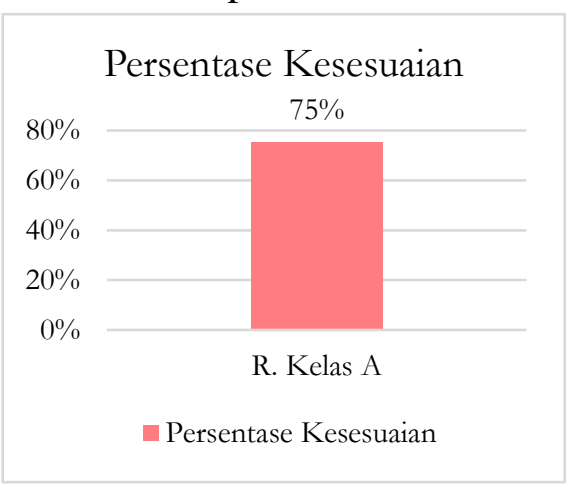

Gambar 10. Diagram Persentase Kesesuaian Kondisi Fisik Sarana Ruang Kelas Kompetensi Keahlian DPIB SMKN 56 Jakarta

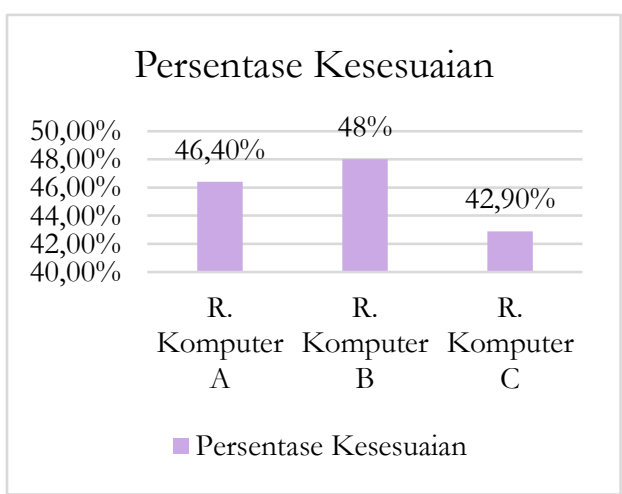

Gambar 11. Diagram Persentase Kesesuaian Kondisi Fisik Sarana Ruang Praktik Komputer Kompetensi Keahlian DPIB SMKN 56 Jakarta 
Kesesuaian Standar Sarana... (R. Eka/ hal. 1-10)

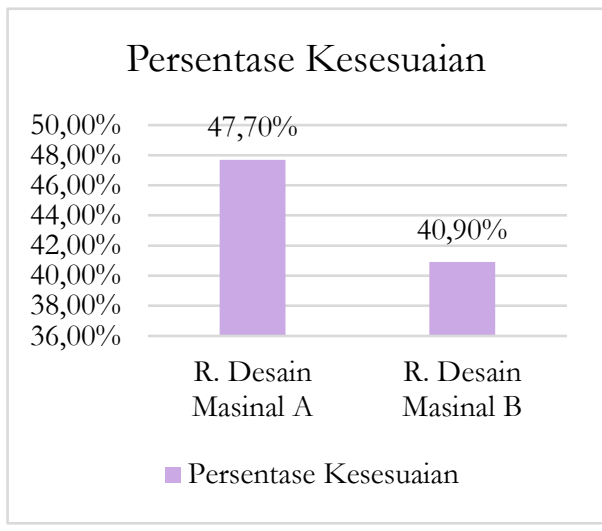

Gambar 12. Diagram Persentase Kesesuaian Kondisi Fisik Sarana Ruang Praktik Desain Masinal Kompetensi Keahlian DPIB SMKN 56 Jakarta

Hasil persentase kesesuaian kondisi fisik sarana ruang kelas pada kompetensi keahlian DPIB di SMKN 35 Jakarta sebesar $75 \%$ termasuk kategori sesuai. Hal ini menandakan bahwa sarana yang ada pada ruang kelas layak untuk menunjang kegiatan pembelajaran. Sedangkan pada kesesuaian kondisi fisik sarana ruang praktik komputer didapatkan persentase sebesar $57,1 \%$ dengan kategori sesuai. Hal ini menandakan bahwa sarana yang ada pada ruang praktik layak untuk menunjang kegiatan pembelajaran. Pada kekurangan sarana yang ada, sekolah dapat melakukan kegiatan prosedur pengadaan sarana dengan melakukan pembelian, perbaikan, pembuatan sendiri, maupun menerima bantuan/hibah. Terkait sarana yang sudah sesuai diperlukan proses pemeliharaan dan perawatan sarana. Agusti dkk (2014, p. 53) menyatakan bahwa ketersediaan sarana yang memadai dapat menunjang keberhasilan pendidikan dan dapat meningkatkan mutu pendidikan. Sependapat dengan itu, Siregar (2019, p. 7) juga menyatakan bahwa secara tidak langsung sarana pendidikan dapat meningkatkan kepuasan siswa yang pada akhirnya dapat mempengaruhi prestasi belajar siswa baik dalam bidang akademik maupun non akademik.

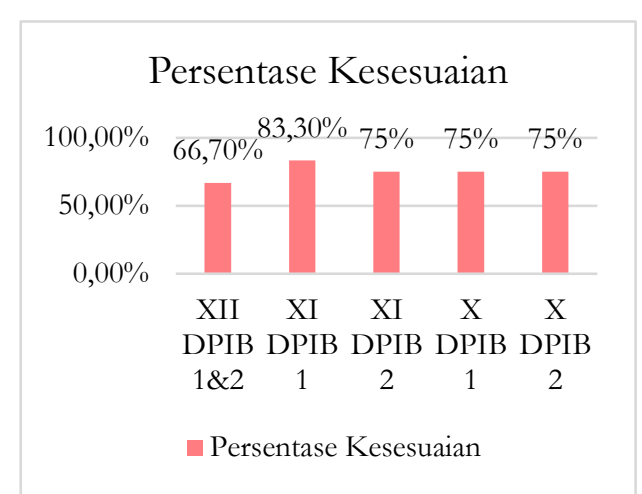

Gambar 13. Diagram Persentase Kesesuaian Kondisi Fisik Sarana Ruang Kelas Kompetensi Keahlian DPIB SMKN 35 Jakarta

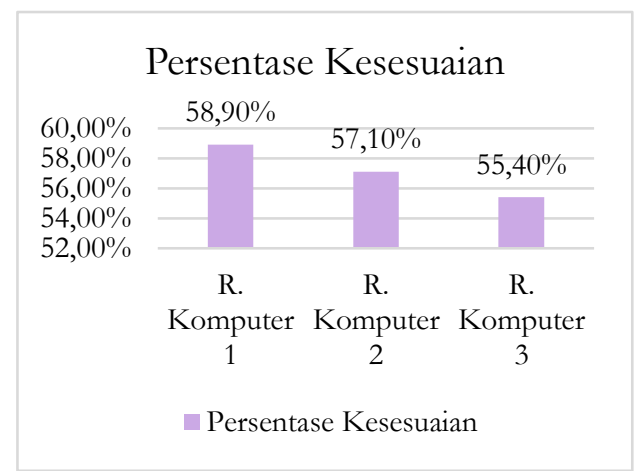

Gambar 14. Diagram Persentase Kesesuaian Kondisi Fisik Sarana Ruang Praktik Komputer Kompetensi Keahlian DPIB SMKN 35 Jakarta

\section{SIMPULAN}

Berdasarkan hasil analisis dapat disimpulkan bahwa pada beberapa sarana dan prasarana di kompetensi keahlian DPIB SMKN 56 Jakarta dan SMKN 35 Jakarta memerlukan prosedur pengadaan sarana dan prasarana. Sarana dan prasarana yang sudah sesuai dengan standar diperlukan proses pemeliharaan dan perawatan dari sekolah. Kebutuhan sarana dan prasarana kedua sekolah diharapkan dapat terpenuhi sesuai dengan standar minimum yang berlaku. Sarana dan prasarana yang sesuai dapat berpengaruh baik bagi kegiatan pembelajaran. 


\section{DAFTAR RUJUKAN}

Agusti, R. D., Handoyo, S. S. and Musalamah, S. (2014) 'Analisis Pelaksanaan Prosedur Operasional Standar Sarana dan Prasarana Belajar Laboratorium Berdasarkan Manajemen Mutu ISO 9001:2008 \& IWA 2:2007 Di Jurusan Teknik Sipil Universitas Negeri Jakarta', Jurnal Pensil FT UNJ, 3, p. 53.

Elviana (2015) Kajian Kelayakan Ruang Gambar Program Keahlian Teknik Bangunan Di Smk Negeri 3 Yogyakarta. Universitas Negeri Yogyakarta.

Haryanto, F. A. R. (2016) Evaluasi Standar Sarana dan Prasarana Bengkel Program Keahlian Teknik Kendaraan Ringan SMK Negeri Se-Kabupaten Sleman Berdasarkan Kurikulum 2013 Ditinjau Dari Permendiknas No 40 Tahun 2008. Universitas Negeri Yogyakarta.

Havidotinnisa, S. (2016) Kontribusi Pemanfaatan Sarana dan Prasarana Terhadap Kinerja Pembelajara Sekolah Menengah Kejuruan Jamblang Kabupaten Cirebon. Universitas Pendidikan Indonesia.

Hidayatuloh, M. N. (2019) Kelayakan Sarana dan Prasarana Bengkel Praktik Teknik Kendaraan Ringan Di SMK Piri Sleman. Universitas Negeri Yogyakarta.

Legiwati, N. (2016) 'Pengaruh Pemanfaatan Sarana dan Prasarana Pembelajaran dan Motivasi Belajar Terhadap Hasil Belajar Siswa Kelas VII SMPN 3 Grati Satap Kabupaten Pasuruan', Jurnal Penelitian dan Pendidikan IPS, 10, p. 295.
Liliani, F., Sumartono, B. G. and Okianna (2019) 'Analisis Sarana dan Prasarana Pendidikan Pada Program Keahlian Akuntansi Di SMK Negeri 1 Kabupaten Sanggau', Jurnal Pendidikan, 8, p. 2.

Oktariansyah, F., Iriani, T. and Maulana, A. (2019) 'Identifikasi Kemampuan Kognitif Siswa Dalam Hasil Belajar Autocad Kelas XI Di SMKN 56 Jakarta', Pendidikan Teknik Sipil, 8.

Pratama, G. N. I. P., Hidayat, N., \& Wahyuni, I. (2020). Peningkatan Keterampilan Pembelajaran Micro Teaching Berbasis Viduk (Video Unjuk Kerja) pada Mahasiswa Pendidikan Teknik Sipil dan Perencanaan, FT, UNY. Jurnal Pendidikan Teknik Sipil, 2(1), 13-23.

Putri, D. A. K., Adi, B. W. and Sunarto (2016) 'Pengaruh Sarana Prasarana Sekolah dan Motivasi Belajar Siswa Terhadap Prestasi Belajar Siswa Pemasaran DI SMK Negeri 1 Sukoharjo Tahun Ajaran 2015/2016', Jurnal Pendidikan, 2, p. 11.

Rahardiani, A. P., Sukatiman and Haris, A. (2017) 'Analisis Kelayakan Sarana dan Prasarana Praktik di Bengkel Teknik Konstruksi Batu dan Beton SMK Negeri 5 Surakarta', Jurnal Pendidikan, 3.

Sarifah, N. (2017) 'Evaluasi Ruang Gambar Manual Kompetensi Keahlian Desain Pemodelan dan Informasi Bangunan di SMKN 1 Pajangan', Pendidikan Teknik Sipil, 6, pp. 1-2.

Siregar, S. N. A. (2019) Manajemen Sarana dan Prasarana Dalam Meningkatkan Mutu Pembelajaran Di MTs. Al Hasanah Medan. Universitas Islam Negeri Sumatera Utara. 
Sudiyono and Alip, M. (2016) 'Evaluasi Sarana dan Prasarana Bengkel Praktik SMK Teknik Pemesinan Di Kota Semarang Berdasarkan Kebutuhan Kurikulum', Jurnal Pendidikan Vokasi, 6, p. 81.

Syafiq, A. (2018) Kelayakan Sarana dan Prasarana Praktik Ditinjau Dari Standar Sarana dan Prasarana Berdasarkan Peraturan Pemerintah No. 40 Tahun 2008 Jurusan TKR SMK Ma'arif 1 Piyungan. Universitas Negeri Yogyakarta.

Triono, K. (2013) Kesesuaian Sarana Dengan Tuntutan Kompetensi Pada Jurusan Teknik Gambar Bangunan Di SMK Negeri 1 Sedayu. Universitas Negeri Yogyakarta.

Triyono, B. M., Mohib, N., Kassymova, G. K., Pratama, G. N., Adinda, D., \& Arpentieva, M. R. (2020). The Profile Improvement of Vocational School Teachers' Competencies. Vysshee obrazovanie $v$ Rossii= Higher Education in Russia, 29(2), 151-158. 